\title{
Methanobacterium movens sp. nov. and Methanobacterium flexile sp. nov., isolated from lake sediment
}

Correspondence

Xiuzhu Dong

dongxz@im.ac.cn

\author{
Jinxing Zhu, ${ }^{1,2}$ Xiaoli Liu ${ }^{1}$ and Xiuzhu Dong ${ }^{1}$ \\ ${ }^{1}$ State Key Laboratory of Microbial Resources, Institute of Microbiology, Chinese Academy of \\ Sciences, Beijing 100101, PR China \\ ${ }^{2}$ Graduate University, Chinese Academy of Sciences, Beijing 100049, PR China
}

Methanogenic archaea are hitherto the only known organisms that generate methane as the final product of energy metabolism (Garcia, 1990), so therefore they play a key role in global methane emission. However, despite their common energy metabolism pathway, methanogens inhabit extremely diverse environments, which range from frozen permafrost and tundra to hot vents with temperatures above $100{ }^{\circ} \mathrm{C}$. They are distributed in almost all anoxic niches, such as freshwater and marine sediments, digestive and intestinal tracts of animals and anaerobic waste digesters (Jones et al., 1987). The majority of rod-shaped methanogens are affiliated with the order Methanobacteriales, which consists of three mesophilic genera (Methanobacterium, Methanobrevibacter and Methanosphaera) and two thermophilic or hyperthermophilic genera (Methanothermobacter and Methanothermus). All methanogens in the order Methanobacteriales are capable of using $\mathrm{H}_{2} / \mathrm{CO}_{2}$ to generate methane, except for Methanosphaera stadtmanae, which produces methane by reducing methanol with $\mathrm{H}_{2}$ (Thauer,

The GenBank/EMBL/DDBJ accession numbers for the 16S rRNA gene and mcrA sequences of strain TS-2 ${ }^{\top}$ are EU366499 and HM802934, respectively, and those for strain $\mathrm{GH}^{\top}$ are EU333914 and HM802935, respectively.

A supplementary figure is available with the online version of this paper.
1998). In addition, many also utilize formate or a few simple alcohols. During a survey of methanogens in two lakes of the Qaidam basin, China, we isolated 10 rod-shaped methanogenic strains by using $\mathrm{H}_{2} / \mathrm{CO}_{2}$ as the carbon substrate. Two strains, designated TS-2 ${ }^{\mathrm{T}}$ and $\mathrm{GH}^{\mathrm{T}}$, were identified on the basis of phylogenetic and phenotypic data as members of the genus Methanobacterium. Of the remaining eight strains, one was closely related to strain $\mathrm{TS}-2^{\mathrm{T}}$, four were related to strain $\mathrm{GH}^{\mathrm{T}}$ and two were identified as members of Methanobacterium formicicum. Strains TS- $2^{\mathrm{T}}$ and $\mathrm{GH}^{\mathrm{T}}$ were isolated from sediment samples collected from Tuosu lake and Gahai lake, respectively, in the Qaidam basin, Qinghai province, China.

Hungate anaerobic techniques were used for isolation and culture (Hungate, 1969). Pre-reduced basal medium was prepared as described by Zehnder \& Wuhrmann (1977) except that sodium acetate was omitted. For routine cultivation, the medium was dispensed into screw-capped tubes sealed with butyl rubber stoppers and the gas phase was $\mathrm{H}_{2} / \mathrm{CO}_{2}(80: 20, \mathrm{v} / \mathrm{v} ; 150 \mathrm{kPa})$. All inoculations and transfers were performed anaerobically with syringes and all cultures were incubated at $37{ }^{\circ} \mathrm{C}$ in the dark. Sediment samples $(1 \mathrm{ml})$ were inoculated into $5 \mathrm{ml}$ basal medium containing $0.5 \mathrm{~g}$ penicillin $\mathrm{l}^{-1}$ (final concentration) and cultured under $\mathrm{H}_{2} / \mathrm{CO}_{2}$ for 4 weeks. After a large amount of 
methane had been produced, the enrichments were serially diluted and the Hungate rolling tube technique was applied. Colonies were observed in the tubes after 14 days and those that produced fluorescence under UV light at a wavelength of $420 \mathrm{~nm}$ (model 2071, max. 100 Watts; American Optical) were picked for further purification. Culture purity was examined periodically by monitoring Gram-stained cell morphology with normal bright-field microscopy as well as by the absence of growth in rich media, such as peptone-yeast extract-glucose broth. The production of methane was determined by gas chromatography (GC-14B; Shimadzu) as described by Kotelnikova et al. (1993). Methanobacterium alcaliphilum DSM $3387^{\mathrm{T}}$ and Methanobacterium formicicum DSM $1535^{\mathrm{T}}$ were purchased from the DSMZ and Methanobacterium beijingense $8-2^{\mathrm{T}}$ was obtained from our laboratory collection.

Exponential-phase cells of strains $\mathrm{TS}-2^{\mathrm{T}}$ and $\mathrm{GH}^{\mathrm{T}}$ were used for morphological examination by transmission electron microscopy (JEM-1400; JEOL). Motility of cells was observed by phase-contrast microscopy (BH-2; Olympus). Both isolates were Gram-staining-positive rods (about $0.3-0.5 \times 2-5 \mu \mathrm{m})$. Strain $\mathrm{TS}-2^{\mathrm{T}}$ was motile with one or two polar flagella (Fig. 1a), while strain $\mathrm{GH}^{\mathrm{T}}$ had no flagella. Strain $\mathrm{GH}^{\mathrm{T}}$ grew as single cells under low pressure $\mathrm{H}_{2}\left(\mathrm{H}_{2} / \mathrm{CO}_{2} / \mathrm{N}_{2} ; 40: 10: 50\right.$, v/v; $\left.100-150 \mathrm{kPa}\right)$ (Fig. 1b), but formed long chains with more than 10 cells in formate or under high pressure $\mathrm{H}_{2} / \mathrm{CO}_{2}(80: 20, \mathrm{v} / \mathrm{v} ; 100-250 \mathrm{kPa})$ (Fig. 1c). Cells of both isolates resisted disruption with $1 \%$ (w/v) SDS or hypotonic solution. Colonies of both isolates were greyish white, opaque and round with entire edges and reached a diameter of $0.5-1.0 \mathrm{~mm}$ after $1-2$ weeks of cultivation under $\mathrm{H}_{2} / \mathrm{CO}_{2}$.

The two isolates grew strictly anaerobically and did not grow in the presence of air. Substrate utilization was tested by measuring methane production in basal medium with each of formate, acetate, methanol, ethanol, trimethylamine, isobutanol and 2-propanol $(10 \mathrm{mM})$, with $\mathrm{N}_{2} / \mathrm{CO}_{2}$ ( $80: 20, v / v ; 101 \mathrm{kPa}$ ) replacing $\mathrm{H}_{2} / \mathrm{CO}_{2}$ as the gas phase. Strain TS- $2^{\mathrm{T}}$ only used $\mathrm{H}_{2} / \mathrm{CO}_{2}$ and strain $\mathrm{GH}^{\mathrm{T}}$ used both $\mathrm{H}_{2} / \mathrm{CO}_{2}$ and formate for growth and methane production. Acetate, methanol, ethanol, trimethylamine, isobutanol and 2-propanol were not used. Growth factors were determined by measuring growth in basal medium by omitting one component in each test (vitamins, yeast extract, peptone, acetate). Strains $\mathrm{TS}-2^{\mathrm{T}}$ and $\mathrm{GH}^{\mathrm{T}}$ grew well without peptone and vitamins, whereas yeast extract $(0.1-$ $2 \%, \mathrm{w} / \mathrm{v}$ ) was indispensable. The $\mathrm{pH}$ range for growth was measured by adjusting the $\mathrm{pH}$ of the medium with $10 \%$ $(\mathrm{w} / \mathrm{v}) \mathrm{NaOH}$ or $10 \%(\mathrm{w} / \mathrm{v}) \mathrm{HCl}$. The temperature for growth was measured in a water bath with temperature controller. Growth with $0-1000 \mathrm{mM} \mathrm{NaCl}$ was measured in basal medium with $\mathrm{H}_{2} / \mathrm{CO}_{2}$ as the gas phase. Optimal growth was determined by measuring methane production at $8-24 \mathrm{~h}$ interval for 10 days. Strains $\mathrm{TS}-2^{\mathrm{T}}$ and $\mathrm{GH}^{\mathrm{T}}$ grew at $10-50{ }^{\circ} \mathrm{C}$ (optimum $35-38{ }^{\circ} \mathrm{C}$ ), at $\mathrm{pH} 6.0-9.0$ and 6.5-9.5, respectively, and with 1.7 and $1.0 \mathrm{M} \mathrm{NaCl}$, respectively (optimum $0-0.3$ and $0-0.1 \mathrm{M}$, respectively) (see
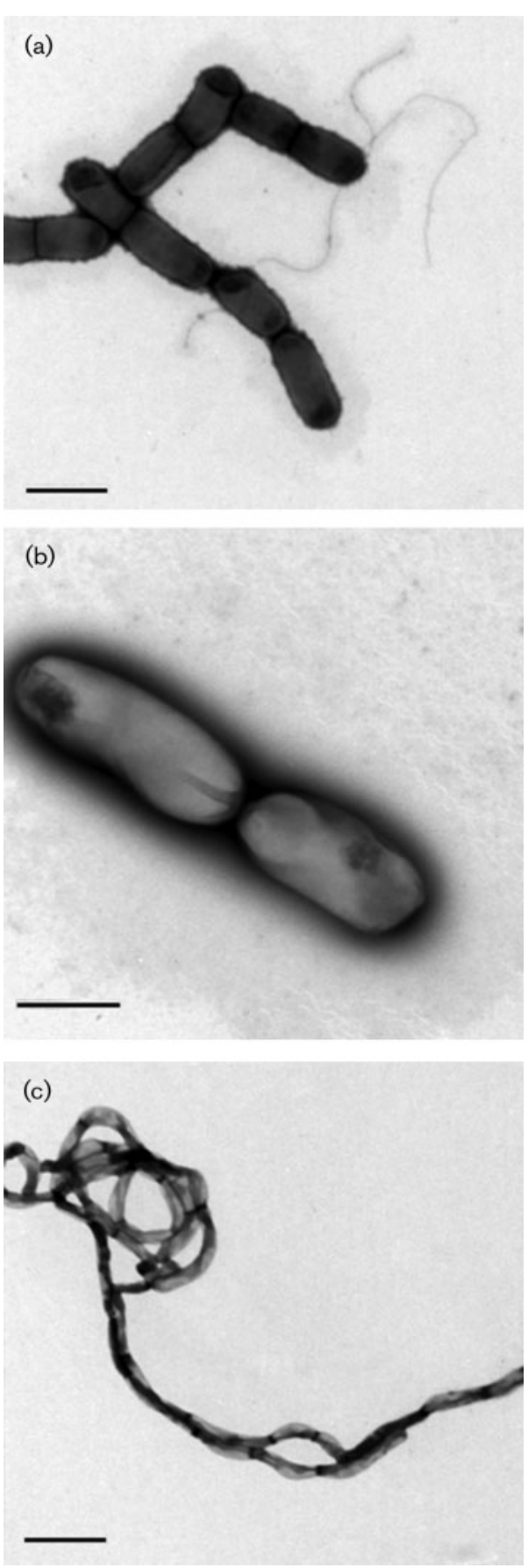

Fig. 1. Transmission electron micrographs of cells of strain TS-2 ${ }^{\top}$ (a), strain $\mathrm{GH}^{\top}$ under low pressure $\mathrm{H}_{2}$ (b) and strain $\mathrm{GH}^{\top}$ in formate (c), after negative staining with uranyl acetate. Bars, $1 \mu \mathrm{m}$ (a), $0.5 \mu \mathrm{m}$ (b), $2.0 \mu \mathrm{m}$ (c).

Supplementary Fig. S1, available in IJSEM Online). The specific growth rate was calculated from the linear part of the methane production curve in basal medium under $\mathrm{H}_{2} /$ $\mathrm{CO}_{2}$ at $\mathrm{pH} 7.2$ and $37{ }^{\circ} \mathrm{C}$, according to the method of Lai et al. (2000), and was determined to be 0.027 and $0.032 \mathrm{~h}^{-1}$ for strains TS-2 ${ }^{\mathrm{T}}$ and $\mathrm{GH}^{\mathrm{T}}$, respectively. 
Genomic DNA extraction and purification were performed according to Jarrell et al. (1992). For phylogenetic analysis, the almost-complete sequence of the $16 \mathrm{~S}$ rRNA gene and a partial sequence of mcrA (alpha subunit of methyl-coenzyme M reductase) were determined. The $16 \mathrm{~S}$ rRNA gene was amplified using the archaea-specific primer if (Embley et al., 1992) and the prokaryote primer 1541R (Sung et al., 2006). Purified PCR products (about $1400 \mathrm{bp}$ ) were cloned into the pUCm-T vector (Takara) and sequenced by Bioasia. The $m c r A$ gene was amplified using the primer set ME1 and ME2 (Hales et al., 1996) and sequenced as described for the 16S rRNA gene. The $16 \mathrm{~S}$ rRNA gene sequences and the deduced amino acid sequences for McrA were submitted to GenBank to search for related sequences using BLAST (Altschul et al., 1990), which were then aligned using CLUSTAL_X (Thompson et al., 1997). Phylogenetic trees based on $16 \mathrm{~S}$ rRNA gene (Fig. 2a) and McrA (Fig. 2b) sequences were constructed using the neighbourjoining algorithm in MEGA3.1 (Kumar et al., 2004). The 16S rRNA gene sequence analysis indicated that the two isolates were affiliated with the genus Methanobacterium but represented two novel species. Strain TS- $2^{\mathrm{T}}$ was most closely related to Methanobacterium alcaliphilum NBRC $105226^{\mathrm{T}}$ (96\% 16S rRNA gene sequence similarity). The McrA sequence analysis also showed that strains TS- $2^{\mathrm{T}}$ and $\mathrm{GH}^{\mathrm{T}}$ were most closely related to Methanobacterium alcaliphilum NBRC $105226^{\mathrm{T}}$ (96 and $91 \%$ MrcA sequence similarity, respectively).

The DNA G + C content of each isolate was determined using both thermal denaturation and HPLC with Escherichia coli $\mathrm{K}-12$ as the reference strain. The $\mathrm{G}+\mathrm{C}$ content of strain TS- ${ }^{\mathrm{T}}$ was $39.1 \pm 0.8 \mathrm{~mol} \%\left(T_{\mathrm{m}}\right)$ and $39.5 \pm 0.6 \mathrm{~mol} \%$ (HPLC) and of strain $\mathrm{GH}^{\mathrm{T}}$ was $36.4 \pm 0.6 \mathrm{~mol} \%\left(T_{\mathrm{m}}\right)$ and $37.3 \pm 0.3 \mathrm{~mol} \%$ (HPLC). DNA-DNA relatedness was determined using the initial reassociation rate method of Owen \& Pitcher (1985) with a hybridization temperature of $65{ }^{\circ} \mathrm{C}$ and a UV800 spectrophotometer (Beckman). DNADNA relatedness between the two isolates was determined to be $36-42 \%$ and between strains $\mathrm{TS}-2^{\mathrm{T}}$ and $\mathrm{GH}^{\mathrm{T}}$ and Methanobacterium alcaliphilum DSM $3387^{\mathrm{T}}$ was $39-49 \%$ and $41-53 \%$, respectively.

The differential phenotypic characteristics of strains TS- $2^{\mathrm{T}}$ and $\mathrm{GH}^{\mathrm{T}}$ and the type strains of most of the recognized species in the genus Methanobacterium are summarized in Table 1. Strain TS $-2^{\mathrm{T}}$ differed from all members of the genus Methanobacterium by its flagellar mobility. Strains TS $-2^{\mathrm{T}}$ and $\mathrm{GH}^{\mathrm{T}}$ differed from Methanobacterium alcaliphilum by their optimal growth at neutral $\mathrm{pH}$. Strains TS-2 ${ }^{\mathrm{T}}$ and $\mathrm{GH}^{\mathrm{T}}$ differed from Methanobacterium aarhusense and Methanobacterium ivanovii by their inability to grow at $45{ }^{\circ} \mathrm{C}$. Strains TS $-2^{\mathrm{T}}$ and $\mathrm{GH}^{\mathrm{T}}$ differed from Methanobacterium petrolearium by not requiring acetate for growth. Strain TS- $2^{\mathrm{T}}$ differed from strain $\mathrm{GH}^{\mathrm{T}}$, Methanobacterium beijingense, Methanobacterium formicicum and Methanobacterium oryzae by not producing methane from formate.

On the basis of phylogenetic, chemotaxonomic and physiological differences, strains $\mathrm{TS}-2^{\mathrm{T}}$ and $\mathrm{GH}^{\mathrm{T}}$ represent two separate novel species of the genus Methanobacterium,

(a)

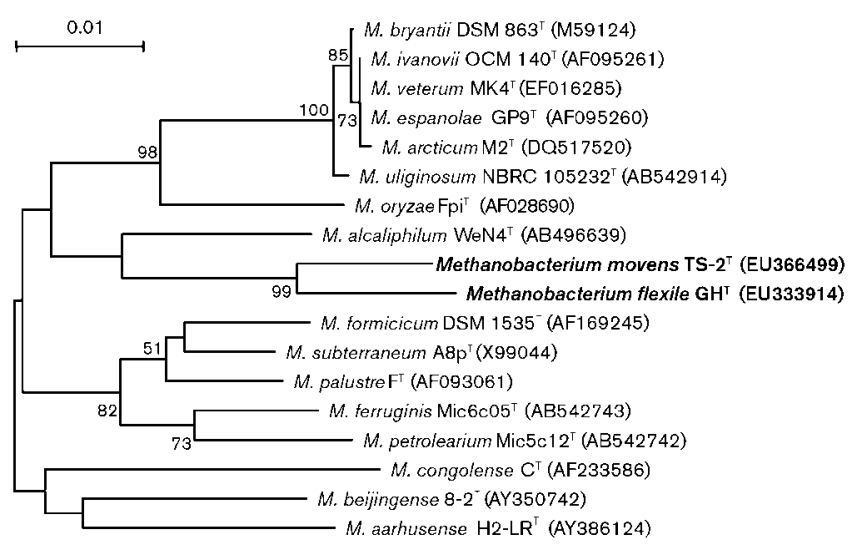

(b)

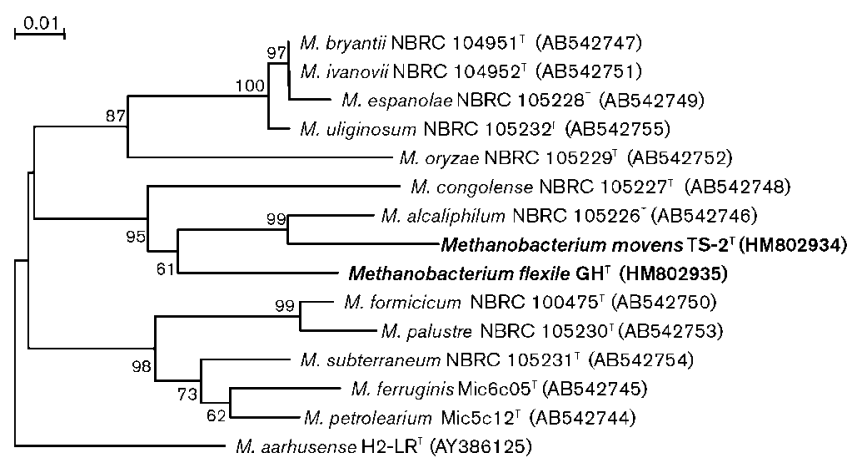

Fig. 2. Neighbour-joining phylogenetic trees showing the positions of strains TS $-2^{\top}$ and $\mathrm{GH}^{\top}$ within the genus Methanobacterium, based on sequences for the $16 \mathrm{~S}$ rRNA gene (1294 nucleotides) (a) and McrA (371 amino acids) (b). Bootstrap values ( $>50 \%$ ) based on 1000 replications are shown at branch nodes. Bars, 0.01 evolutionary distance. 
Table 1. Characteristics differentiating strains $\mathrm{TS}-2^{\top}$ and $\mathrm{GH}{ }^{\top}$ from type strains of species of the genus Methanobacterium

Strains: 1, TS-2 ${ }^{\mathrm{T}} ; 2, \mathrm{GH}^{\mathrm{T}} ; 3$, M. alcaliphilum DSM $3387^{\mathrm{T}}$ (Worakit et al., 1986); 4, M. aarhusense H2-LR ${ }^{\mathrm{T}}$ (Shlimon et al., 2004); 5, M. congolense $\mathrm{C}^{\mathrm{T}}$ (Cuzin et al., 2001); 6, M. beijingense 8-2 ${ }^{\mathrm{T}}$ (Ma et al., 2005); 7, M. formicicum DSM 1535 ${ }^{\mathrm{T}}$ (Boone, 2001); 8, M. oryzae $\mathrm{FPi}^{\mathrm{T}}$ (Joulian et al., 2000); 9, M. bryantii M.o.H. ${ }^{\mathrm{T}}$ (Boone, 2001); 10, M. espanolae $\mathrm{GP}^{\mathrm{T}}{ }^{\mathrm{T}}$ (Patel et al., 1990); 11, M. ivanovii Ivanov $^{\mathrm{T}}$ (Jain et al., 1987). NG, No growth but alcohols are oxidized; +, positive; -, negative; ND, no data available.

\begin{tabular}{|c|c|c|c|c|c|c|c|c|c|c|c|}
\hline Characteristic & 1 & 2 & 3 & 4 & 5 & 6 & 7 & 8 & 9 & 10 & 11 \\
\hline Isolation source & Tuosu lake & Gahai lake & Alkaline lake & $\begin{array}{l}\text { Marine } \\
\text { sediment }\end{array}$ & $\begin{array}{c}\text { Anaerobic } \\
\text { digester }\end{array}$ & $\begin{array}{c}\text { Anaerobic } \\
\text { digester }\end{array}$ & $\begin{array}{c}\text { Sewage } \\
\text { sludge } \\
\text { digester }\end{array}$ & Rice field & $\begin{array}{c}\text { Anaerobic } \\
\text { digester }\end{array}$ & Sludge & Rock core \\
\hline \multicolumn{12}{|l|}{ Substrate } \\
\hline $\mathrm{CO}_{2}$ & + & + & + & + & + & + & + & + & + & + & + \\
\hline Formate & - & + & - & - & - & + & + & + & - & - & - \\
\hline Secondary alcohols & - & - & $-^{*}$ & - & NG & $-^{*}$ & - & - & NG & NG & - \\
\hline Acetate requirement & - & - & - & - & ND & - & - & $\mathrm{ND}$ & - & ND & - \\
\hline \multicolumn{12}{|l|}{ Optimum growth } \\
\hline Temperature $\left({ }^{\circ} \mathrm{C}\right)$ & $35-38$ & $35-38$ & 37 & 45 & $37-42$ & 37 & $37-45$ & 40 & $37-39$ & 35 & 45 \\
\hline $\mathrm{pH}$ & $7.2-7.5$ & $7.0-7.5$ & $8.1-9.1$ & $7.5-8.0$ & 7.2 & 7.2 & $7.2^{*}$ & 7 & $6.9-7.2$ & $5.6-6.2$ & $7.0-7.4$ \\
\hline $\mathrm{NaCl}$ for growth $(\mathrm{M})$ & $0-0.3$ & $0-0.1$ & $0-0.6^{*}$ & $0.05-0.9$ & $\mathrm{ND}$ & $0-0.5$ & $0-0.5^{*}$ & $0-0.4$ & ND & ND & ND \\
\hline Motility & + & - & - & - & - & - & - & - & - & - & - \\
\hline DNA G $+\mathrm{C}$ content $(\mathrm{mol} \%) \dagger$ & $\begin{array}{c}39.1 \pm 0.8 \\
\left(T_{\mathrm{m}}\right)\end{array}$ & $\begin{array}{c}36.4 \pm 0.6 \\
\left(T_{\mathrm{m}}\right)\end{array}$ & $57(\mathrm{Bd})$ & $34.9(\mathrm{Lc})$ & $39.5(\mathrm{Lc})$ & $38.9(\mathrm{Lc})$ & $\begin{array}{r}41-42 \\
(\mathrm{Bd})\end{array}$ & $31(\mathrm{Lc})$ & $\begin{array}{r}33-38 \\
(\mathrm{Bd})\end{array}$ & $34\left(T_{\mathrm{m}}\right)$ & $36.6\left(T_{\mathrm{m}}\right)$ \\
\hline
\end{tabular}

${ }^{\star}$ Data were taken from this study.

$\dagger \mathrm{Bd}$, buoyant density; Lc, HPLC; $T_{\mathrm{m}}$, melting point. 
for which the names Methanobacterium mobile sp. nov. and Methanobacterium flexile sp. nov., respectively, are proposed.

\section{Description of Methanobacterium movens sp. nov.}

Methanobacterium movens (mo'vens. L. part. adj. movens movable).

Cells are rods $(0.4-0.5 \times 2-5 \mu \mathrm{m})$, occurring singly or in pairs and motile by one or two polar flagella. Uses only $\mathrm{H}_{2} /$ $\mathrm{CO}_{2}$ for methane production. Acetate, methanol, ethanol, trimethylamine, isobutanol and 2-propanol are not used. Yeast extract is indispensable for growth. Grows optimally at 35-38 ${ }^{\circ} \mathrm{C}$ and $\mathrm{pH}$ 7.2-7.5. The DNA G $+\mathrm{C}$ content of the type strain is $39.1 \pm 0.8 \mathrm{~mol} \%\left(T_{\mathrm{m}}\right)$ and $39.5 \pm 0.6 \mathrm{~mol} \%$ (HPLC).

The type strain $\mathrm{TS}-2^{\mathrm{T}}\left(=\mathrm{AS} 1.5093^{\mathrm{T}}=\mathrm{JCM} 15415^{\mathrm{T}}\right)$, was isolated from the sediment of Tuosu lake, China.

\section{Description of Methanobacterium flexile sp. nov.}

Methanobacterium flexile (fle'xi.le. L. neut. adj. flexile pliable, flexile).

Cells are rods $(0.3-0.5 \times 2-5 \mu \mathrm{m})$. Utilizes both $\mathrm{H}_{2} / \mathrm{CO}_{2}$ and formate for methane production. Chains of cells are formed in formate or under high pressure $\mathrm{H}_{2} / \mathrm{CO}_{2}(80: 20$, $\mathrm{v} / \mathrm{v} ; 100-250 \mathrm{kPa}$ ), and single cells are formed under lower pressure $\mathrm{H}_{2}\left(\mathrm{H}_{2} / \mathrm{CO}_{2} / \mathrm{N}_{2} ; 40: 10: 50, \mathrm{v} / \mathrm{v} ; 100-150 \mathrm{kPa}\right)$. Grows optimally at $35-38{ }^{\circ} \mathrm{C}$ and $\mathrm{pH} 7.0-7.5$. Yeast extract is indispensable for growth. The DNA G $+\mathrm{C}$ content of the type strain is $36.4 \pm 0.6 \mathrm{~mol} \%\left(T_{\mathrm{m}}\right)$ and $37.3 \pm 0.3 \mathrm{~mol} \%$ (HPLC).

The type strain is $\mathrm{GH}^{\mathrm{T}}\left(=\mathrm{AS} 1.5092^{\mathrm{T}}=\mathrm{JCM} 15416^{\mathrm{T}}\right)$, isolated from the sediment of Gahai lake, China.

\section{Acknowledgements}

This study was supported by the National Science Foundation of China (30830007, 30621005).

\section{References}

Altschul, S. F., Gish, W., Miller, W., Myers, E. W. \& Lipman, D. J. (1990). Basic local alignment search tool. J Mol Biol 215, 403-410.

Boone, D. R. (2001). Genus I. Methanobacterium Kluyver and Niel 1936, 399, ${ }^{\mathrm{AL}}$ emend. Balch and Wolfe in Balch, Fox, Magrum, Woese and Wolfe 1979, 284. In Bergey's Manual of Systematic Bacteriology, 2nd edn, vol. 1, pp. 215-218. Edited by D. R. Boone, R. W. Castenholz \& G. M. Garrity. New York: Springer.

Cuzin, N., Ouattara, A. S., Labat, M. \& Garcia, J. L. (2001). Methanobacterium congolense sp. nov., from a methanogenic fermentation of cassava peel. Int J Syst Evol Microbiol 51, 489-493.

Embley, T. M., Finlay, B. J., Thomas, R. H. \& Dyal, P. L. (1992). The use of rRNA sequences and fluorescent probes to investigate the phylogenetic positions of the anaerobic ciliate Metopus palaeformis and its archaeobacterial endosymbiont. J Gen Microbiol 138, 1479-1487.
Garcia, J. (1990). Taxonomy and ecology of methanogens. FEMS Microbiol Rev 87, 297-308.

Hales, B. A., Edwards, C., Ritchie, D. A., Hall, G., Pickup, R. W. \& Saunders, J. R. (1996). Isolation and identification of methanogenspecific DNA from blanket bog peat by PCR amplification and sequence analysis. Appl Environ Microbiol 62, 668-675.

Hungate, R. (1969). The roll-tube method for cultivation of strict anaerobes. Methods Microbiol 3B, 117-132.

Jain, M. K., Thompson, T. E., Conway de Macario, E. \& Zeikus, J. G. (1987). Speciation of Methanobacterium strain Ivanov as Methanobacterium ivanovii, sp. nov. Syst Appl Microbiol 9, 77-82.

Jarrell, K. F., Faguy, D., Hebert, A. M. \& Kalmokoff, M. L. (1992). A general method of isolating high molecular weight DNA from methanogenic archaea (archaebacteria). Can J Microbiol 38, 65-68.

Jones, W. J., Nagle, D. P., Jr \& Whitman, W. B. (1987). Methanogens and the diversity of archaebacteria. Microbiol Rev 51, 135-177.

Joulian, C., Patel, B. K., Ollivier, B., Garcia, J. L. \& Roger, P. A. (2000). Methanobacterium oryzae sp. nov., a novel methanogenic rod isolated from a Philippines ricefield. Int J Syst Evol Microbiol 50, 525-528.

Kotelnikova, S. V., Obraztsova, A. Ya., Gongadze, G. M. \& Laurinavichius, K. S. (1993). Methanobacterium thermoflexum sp. nov. and Methanobacterium defluvii sp. nov., thermophilic rodshaped methanogens isolated from anaerobic digester sludge. Syst Appl Microbiol 16, 427-435.

Kumar, S., Tamura, K. \& Nei, M. (2004). MEGA3: Integrated software for molecular evolutionary genetics analysis and sequence alignment. Brief Bioinform 5, 150-163.

Lai, M. C., Shu, C. M., Chen, S. C., Lai, L. J., Chiou, M. S. \& Hua, J. J. (2000). Methanosarcina mazei strain O1M9704, methanogen with novel tubule isolated from estuarine environment. Curr Microbiol 41, 15-20.

Ma, K., Liu, X. \& Dong, X. (2005). Methanobacterium beijingense sp. nov., a novel methanogen isolated from anaerobic digesters. Int J Syst Evol Microbiol 55, 325-329.

Owen, R. \& Pitcher, D. (1985). Current methods for estimating DNA base composition and levels of DNA-DNA hybridization. In Chemical Methods in Bacterial Systematics, pp. 63-97. Edited by M. Goodfellow $\&$ E. Minnikin. London: Academic Press.

Patel, G., Sprott, G. \& Fein, J. (1990). Isolation and characterization of Methanobacterium espanolae sp. nov., a mesophilic, moderately acidiphilic methanogen. Int J Syst Bacteriol 40, 12-18.

Shlimon, A. G., Friedrich, M. W., Niemann, H., Ramsing, N. B. \& Finster, K. (2004). Methanobacterium aarhusense sp. nov., a novel methanogen isolated from a marine sediment (Aarhus Bay, Denmark). Int J Syst Evol Microbiol 54, 759-763.

Sung, Y., Ritalahti, K. M., Apkarian, R. P. \& Löffler, F. E. (2006). Quantitative PCR confirms purity of strain GT, a novel trichloroethene-to-ethene-respiring Dehalococcoides isolate. Appl Environ Microbiol 72, 1980-1987.

Thauer, R. K. (1998). Biochemistry of methanogenesis: a tribute to Marjory Stephenson. Microbiology 144, 2377-2406.

Thompson, J. D., Gibson, T. J., Plewniak, F., Jeanmougin, F. \& Higgins, D. G. (1997). The CLUSTAL_X windows interface: flexible strategies for multiple sequence alignment aided by quality analysis tools. Nucleic Acids Res 25, 4876-4882.

Worakit, S., Boone, D. R., Mah, R. A., Abdel-Samie, M.-E. \& ElHalwagi, M. M. (1986). Methanobacterium alcaliphilum sp. nov., an $\mathrm{H}_{2}$-utilizing methanogen that grows at high $\mathrm{pH}$ values. Int $J$ Syst Bacteriol 36, 380-382.

Zehnder, A. \& Wuhrmann, K. (1977). Physiology of a Methanobacterium strain AZ. Arch Microbiol 111, 199-205. 